\title{
MAKNA KESEPAKATAN PARA PIHAK TERHADAP PERUBAHAN MODAL DASAR PERSEROAN TERBATAS
}

\author{
Yohana Feryna \\ Magister Kenotariatan Fakultas Hukum Universitas Brawijaya \\ JI. MT. Haryono No. 169 Malang \\ yohanaferyna@gmail.com
}

\begin{abstract}
The Limited Liability Company regulated by the Government shall issue Government Regulation No. 29 of 2016 concerning Changes in Authorized Capital of Limited Liability Company. The purpose of this journal is to analyze the meaning of the agreement of the parties to the Government Regulation of the Republic of Indonesia Number 29 of 2016, to know the legal consequences of changes in the amount of authorized capital of the Limited Liability Company and to formulate Article in Limited Liability Company Law concerning the amount of authorized capital of Limited Liability Company. Government Regulation of the Republic of Indonesia Number 29 the Year 2016. Government Regulation Number 29 the Year 2016 is the founders of Limited Liability Company can establish Limited Liability Company with authorized capital below fifty million rupiah provided that the agreement of the establishment of the Limited Liability Company has reached conformity or approval by the parties in the establishment of the Limited Liability Company, the change in the capital stock regulation has the legal effect of the absence of legal protection for third parties and the absence of legal certainty.
\end{abstract}

Keywords: The authorized capital, Limited Liability Company, Agreement.

\begin{abstract}
ABSTRAK
Perseroan Terbatas yang diatur dalam Pemerintah mengeluarkan Peraturan Pemerintah Republik Indonesia Nomor 29 Tahun 2016 Tentang Perubahan Modal Dasar Perseroan Terbatas. Tujuan penulisan jurnal ini untuk menganalisis makna kesepakatan para pihak pada Peraturan Pemerintah Republik Indonesia Nomor 29 Tahun 2016, mengetahui akibat hukum dari perubahan besaran modal dasar Perseroan Terbatas tersebut dan menformulasikan Pasal dalam Undang-Undang Perseroan Terbatas terkait besaran modal dasar Perseroan Terbatas. Peraturan Pemerintah Republik Indonesia Nomor 29 Tahun 2016. Peraturan Pemerintah Nomor 29 Tahun 2016 adalah para pendiri Perseroan Terbatas dapat mendirikan Perseroan Terbatas dengan modal dasar dibawah lima puluh juta rupiah asalkan dalam perjanjian pendirian Perseroan Terbatas tersebut telah mencapai kesesuaian atau disetujui oleh para pihak dalam pendirian Perseroan Terbatas, perubahan pengaturan modal dasar tersebut menimbulkan akibat hukum yaitu tidak adanya perlindungan hukum bagi pihak ketiga dan tidak adanya kepastian hukum.
\end{abstract}

Kata Kunci: Modal Dasar, Perseroan Terbatas, Kesepakatan. 
Perseroan Terbatas (untuk selanjutnya akan disingkat PT) sebagai suatu bentuk badan usaha untuk melakukan kegiatan ekonomi dalam kehidupan seharihari tidak lagi dapat diabaikan. Tidak dapat dipungkiri bahwa sebagian besar badan usaha yang berdiri dan menjalankan usaha di Indonesia adalah berbentuk Perseroan Terbatas (PT).

Perseroan Terbatas (PT) diatur dalam Undang-Undang Republik Indonesia Nomor 40 Tahun 2007 tentang Perseroan Terbatas (untuk selanjutnya akan disingkat UUPT Tahun 2007). Pasal 1 angka 1 UUPT Tahun 2007 memberikan pengertian PT sebagai "badan hukum yang merupakan persekutuan modal, yang didirikan berdasarkan perjanjian dan melakukan kegiatan usaha dengan modal dasar yang seluruhnya terbagi dalam saham dan memenuhi persyaratan yang ditetapkan dalam Undang-Undang ini serta peraturan pelaksanaanya."

Persekutuan modal merupakan salah satu elemen penting dalam pendirian PT. Sehingga, hal yang terpenting dalam pendirian dan pelaksanaan PT adalah modal (uang dan barang yang dapat dinilai dengan uang). Hal ini berbeda dengan $\mathrm{CV}$ (Commanditaire Vennootschap) dan firma yang merupakan badan berasosiasi orang. Pengurus (organ) PT dapat berganti-ganti, namun keberadaan PT tetap. Modal yang dimiliki PT tersebut haruslah berupa modal dasar yang berwujud saham/ sero/ andil.

UUPT Tahun 2007 tidak memberikan pengertian dari modal dasar PT, namun Pasal 31 ayat (1) UUPT Tahun 2007 menyebutkan bahwa modal dasar perseroan terdiri atas seluruh nilai nominal saham. Rochmat Soemitro, R.T. Sutantya R. Hadhikusuma dan Sumantoro $(2007,39)$ memberikan pengertian modal dasar sebagai jumlah modal yang disebut dalam akta pendirian PT yang besarnya jumlah tersebut merupakan jumlah maksimal modal dasar perseroan. Besarnya modal dasar tersebut tidak menggambarkan kekuatan finansial dari suatu PT, melainkan hanya mem- perlihatkan jumlah nominal dari semua saham yang dikeluarkan menurut anggaran dasarnya (Sutantya dan Sumantoro, 1992, 52).

Pasal 32 ayat (1) UUPT Tahun 2007 menyatakan bahwa modal dasar PT paling sedikit adalah Rp. 50.000.000,- (lima puluh juta rupiah). Hal tersebut berati dalam pendirian suatu PT diperlukan modal dasar yang tidak kurang dari jumlah batas minimal tersebut dan lebih dari itu tidak dilarang. Persyaratan modal minimal tersebut dimaksudkan agar ketika PT didirikan setidak-tidaknya sudah memiliki modal yakni sebesar modal yang disetor dan juga dapat menjadi jaminan bagi setiap tagihan dari pihak ketiga terhadap PT dan semuanya ini bertujuan untuk memberikan jaminan perlindungan terhadap tagihan pihak ketiga (Handri Raharjo, 2013, 83).

Pasal 32 ayat (2) UUPT Tahun 2007 mengatur mengenai modal dasar minimum dapat diadakan perubahan-perubahan apabila mengenai suatu bidang usaha tertentu yang diatur oleh Undangundang atau Peraturan Pelaksanaan. Penentuan modal dasar minimum yang berbeda ini, sehubungan dengan pemberian izin usaha oleh Pemerintah dalam beberapa hal tertentu yang seringkali dimintakan syarat adanya jaminan "modal dasar" atau "modal disetor" minimum tertentu untuk dapat memperoleh izin usaha (Kansil, 2009, 10).

Pasal 32 ayat (3) UUPT Tahun 2007 memberikan kemungkinan perubahan besaran modal dasar PT yang dapat menyimpangi besaran modal dasar yang telah diatur dalam Pasal 32 ayat (1). Tujuan dari pengaturan tersebut adalah untuk mengantisipasi perubahan keadaan perekonomian, misalnya dalam hal terjadi inflasi. Suatu jumlah tertentu dalam waktu sekarang mungkin saja telah dipandang cukup, namun dalam waktu lima tahun mendatang menjadi tidak memadai lagi. Dengan adanya pasal 32 ayat (3) UUPT Tahun 2007 tersebut, maka perubahan ketentuan pada Pasal 32 ayat (1) tidak perlu melalui revisi atau amandemen UUPT Tahun 2007. Hal tersebut dianggap meng- 


\section{Makna Kesepakatan Para Pihak terhadap Perubahan Modal Dasar Perseroan Terbatas}

Yohana Feryna

hambat kebutuhan perkembangan hukum yang mendesak. Oleh karena itu, perubahan batas minimal modal dasar cukup melalui sarana hukum yang berbentuk Peraturan Pemerintah sehingga tidak perlu melalui proses yang berbelit dengan melibatkan campur tangan badan legislative (Harahap, 2015, 235).

Pemerintah mengeluarkan Peraturan Pemerintah Republik Indonesia Nomor 29 Tahun 2016 tentang Perubahan Modal Dasar Perseroan Terbatas pada tanggal 14 Juli 2016. Pertimbangan Pemerintah dalam mengeluarkan Peraturan Pemerintah ini dapat dilihat dalam bagian menimbang huruf a yaitu untuk memberikan kemudahan berusaha bagi para pengusaha dalam mendirikan badan usaha dalam bentuk PT dan Pemerintah juga perlu untuk memberikan keleluasaan untuk menentukan besaran modal dasar dalam memulai usaha.

Substansi pokok yang diatur dalam Peraturan Pemerintah Nomor 29 Tahun 2016 ini terletak pada Pasal 1 ayat (3) yaitu: "Besaran modal dasar Perseroan Terbatas sebagaimana dimaksud pada ayat (1) ditentukan berdasarkan kesepakatan para pendiri Perseroan Terbatas." Penjelasan pasal tersebut bahwa, penyerahan penentuan besaran modal dasar PT kepada para pendiri PT dimaksudkan sebagai upaya pemerintah untuk menghormati asas kebebasan berkontrak yang memberikan kebebasan seluas-luasnya kepada masyarakat untuk mengadakan perjanjian dalam mendirikan PT berdasarkan ketentuan dalam Hukum Perdata.

Salah satu unsur PT menurut Pasal 1 angka 1 UUPT Tahun 2007 adalah didirikan berdasarkan perjanjian. Hal tersebut berati apabila ditinjau dari segi hukum perjanjian, pendirian PT sebagai badan hukum bersifat kontraktual yakni berdirinya PT merupakan akibat yang lahir dari perjanjian. Pasal 1313 Kitab Undang-Undang Hukum Perdata memberikan definisi perjanjian sebagai "suatu perbuatan dengan mana satu orang atau lebih mengikatkan dirinya terhadap satu orang atau lebih."
Pasal 7 ayat (1) UUPT Tahun 2007 menyatakan bahwa untuk dapat mendirikan PT paling sedikit harus ada 2 (dua) orang. Kurang dari jumlah tersebut adalah tidak mungkin. Hal tersebut dikarenakan satu orang tidak mungkin dapat mengadakan perjanjian dengan dirinya sendiri, jadi harus ada orang lain yang diajak mengadakan perjanjian sehingga ada kata sepakat untuk mendirikan PT.

Bab III Kitab Undang-Undang Hukum Perdata menganut sistem terbuka, artinya hukum memberikan keleluasaan kepada para pihak untuk mengatur sendiri pola hubungan hukumnya. Sistem terbuka dalam buku III Kitab Undang-Undang Hukum Perdata ini tercermin dari substansi Pasal 1338 ayat (1) Kitab Undang-Undang Hukum Perdata yang menyatakan bahwa semua perjanjian yang dibuat secara sah berlaku sebagai undang-undang bagi mereka yang membuatnya."

Sutan Remi Sjahdeini $(1993,47)$ memberikan ruang lingkup asas kebebasan berkontrak menurut hukum perjanjian Indonesia sebagai berikut:

1. Kebebasan untuk membuat atau tidak membuat perjanjian;

2. Kebebasan untuk memilih pihak dengan siapa ia ingin membuat perjanjian;

3. Kebebasan untuk menentukan atau memilih kausa dari perjanjian yang akan dibuatnya;

4. Kebebasan untuk menentukan objek perjanjian;

5. Kebebasan untuk menentukan bentuk suatu perjanjian; dan

6. Kebebasan untuk menerima atau menyimpangi ketentuan undang-undang yang bersifat opsional.

Asas kebebasan berkontrak sebagaimana dinyatakan dalam Pasal 1338 ayat (1) Kitab UndangUndang Hukum Perdata bukan berati bebas dengan tanpa batasan. Sebagai suatu kesatuan yang bulat dan utuh dalam suatu sistem, maka penerapan asas kebebasan berkontrak harus juga dikaitkan 
dengan kerangka pemahaman pasal-pasal atau ketentuan-ketentuan lain, yaitu:

1. Memenuhi syarat-syarat sahnya kontrak (Pasal 1320 Kitab Undang-Undang Hukum Perdata);

2. Untuk mencapainya tujuan para pihak, kontrak harus mempunyai kausa (Pasal 1335 Kitab Undang-Undang Hukum Perdata);

3. Tidak mengandung kausa palsu atau dilarang undang-undang (Pasal 1337 Kitab UndangUndang Hukum Perdata);

4. Tidak bertentangan dengan kepatutan, kebiasaan, kesusilaan dan ketertiban umum (Pasal 1339 Kitab Undang-Undang Hukum Perdata); dan

5. Harus dilaksanakan dengan itikad baik (Pasal 1338 ayat (3) Kitab Undang-Undang Hukum Perdata).

Pendirian PT sebenarnya telah mencerminkan adanya asas kebebasan berkontrak yang tertuang dalam akta pendirian PT. Hal tersebut dibuktikan dengan para pihak bebas untuk memilih dengan siapa ia ingin mendirikan PT, bebas menentukan isi dari anggaran dasar pendirian PT, bebas menentukan nama dan kedudukan perseroan, maksud dan tujuan serta kegiatan usaha perseroan, jangka waktu berdirinya perseroan, besarnya jumlah modal dasar, modal ditempatkan dan modal disetor, bebas untuk menentukan jumlah saham serta bebas menentukan tempat dan tata cara penyelenggaraan Rapat Umum Pemegang Saham (RUPS). Namun kebebasan tersebut juga bukan berati bebas dengan tanpa batasan, contohnya dalam hal kebebasan menentukan modal dasar pendirian PT, para pihak bebas dalam menentukan besaran modal dasar pendirian PT, asalkan tidak kurang dari Rp. 50.000.000,- (lima puluh juta rupiah) sebagaimana yang telah ditetapkan dalam Pasal 32 ayat (1) UUPT Tahun 2007.

Berdasarkan uraian di atas, maka terlihat bahwa dalam pendirian PT memang membutuhkan adanya kesepakatan pendiri PT, selain itu adanya kebebasan antara pendiri PT untuk menentukan isi dari perjanjian pendirian PT. Hal ini menyebabkan adanya kekaburan makna dari "kesepakatan para pihak" yang tertuang dalam Pasal 1 ayat (3) Peraturan Pemerintah Republik Indonesia Nomor 29 Tahun 2016 Tentang Perubahan Modal Dasar Perseroan Terbatas.

Berdasarkan latar belakang di atas dapat dirumuskan 3 rumusan masalah apa makna kesepakatan para pihak pada Pasal 1 ayat (3) Peraturan Pemerintah Republik Indonesia Nomor 29 Tahun 2016 tentang Perubahan Modal Dasar Perseroan Terbatas. Apakah akibat hukum dari perubahan besaran modal dasar PT menjadi kesepakatan para pendiri PT. Bagaimana formulasi terhadap UndangUndang Perseroan Terbatas agar dapat memberikan kepastian hukum bagi para pihak.

\section{Metode Penelitian}

Jenis penelitian ini adalah penelitian yuridis normatif, karena penelitian ini beranjak dari adanya kekaburan makna kesepakatan para pihak pada Pasal 1 ayat (3) Peraturan Pemerintah Republik Indonesia Nomor 29 Tahun 2016 tentang Perubahan Modal Dasar Perseroan Terbatas.

Pendekatan yang digunakan dalam menjawab isu dalam penelitian tesis ini adalah pendekatan undang-undang (statute approach) dan pendekatan sejarah hukum (historical approach). Jenis dan sumber data dalam penelitian ini adalah bahan hukum primer, sekunder dan tersier. Teknik pengumpulan sumber bahan penelitian adalah dengan teknik pengumpulan bahan hukum primer, sekunder dan tersier. Teknik analisis bahan hukum yang digunakan adalah dengan cara metode interpretasi hukum, khususnya metode interpretasi teleologis. 
Makna Kesepakatan Para Pihak Pada Pasal 1 Ayat (3) Peraturan Pemerintah Republik Indonesia Nomor 29 Tahun 2016 Tentang Perubahan Modal Dasar Perseroan Terbatas

Pemerintah mengeluarkan Peraturan Pemerintah Republik Indonesia Nomor 29 Tahun 2016 Tentang Perubahan Modal Dasar Perseroan Terbatas pada tanggal 14 Juli 2016. Konsiderannya, tujuan dari diundangkannya Peraturan Pemerintah adalah untuk memberikan kemudahan berusaha bagi para pengusaha dalam mendirikan badan usaha PT yaitu dengan cara memberikan keleluasaan bagi para pendiri PT untuk menentukan besaran modal dasar dalam memulai usaha, serta melaksanakan ketentuan dalam Pasal 32 ayat (3) UUPT Tahun 2007 yang memberikan peluan untuk merubah besaran modal dasar pendirian PT yang telah diatur dalam Pasal 32 ayat (1) UUPT Tahun 2007 dengan Peraturan Pemerintah.

Substansi pokok Peraturan Pemerintah Republik Indonesia Nomor 29 Tahun 2016 Tentang Perubahan Modal Dasar Perseroan Terbatas ini adalah setiap PT wajib memiliki modal dasar yang wajib dituangkan dalam Anggaran Dasar (AD) yang dimuat dalam akta pendirian PT. selanjutnya dalam Pasal 1 ayat (3) tersebut menerangkan bahwa "Penentuan besaran modal dasar Perseroan Terbatas berdasarkan kesepakatan para pendiri Perseroan Terbatas adalah upaya menghormati asas kebebasan berkontrak yang memberikan kebebasan kepada masyarakat untuk mengadakan perjanjian dalam mendirikan Perseroan Terbatas berdasarkan ketentual dalam Hukum Perdata."

Sifat dari pendirian PT adalah didirikan berdasarkan perjanjian. Hal tersebut berati kesepakatan para pihak adalah syarat mutlak dalam pendirian PT. adanya kesepakatan para pihak dalam pendirian PT dapat dilihat dari adanya kesepakatan para pihak dalam menentukan hal-hal yang essentialia dalam perjanjian pendirian PT salah satunya adalah adanya kesepakatan dalam menen- tukan besaran modal dasar pendirian PT. selain itu, apabila asas kebebasan berkontrak dikaitkan dengan pendirian $\mathrm{PT}$, maka sebenarnya dalam pendirian PT sudah menunjukkan adanya asas kebebasan berkontrak. Contohnya dalam menentukan batas minimal modal dasar.

Kebebasan pendiri PT dalam menentukan modal dasar pendirian PT dikarenakan yang diatur dalam Pasal 32 ayat (1) UUPT Tahun 2007 tersebut merupakan jumlah yang paling rendah yang dibenarkan oleh Undang-Undang untuk dicantumkan dalam Anggaran Dasar (AD), sehingga para pihak bebas dalam menentukan besaran modal dasar pendirian PT, asalkan tidak kurang dari Rp. 50.000.000,- (lima puluh juta rupiah).

Berdasarkan uraian di atas, maka terlihat adanya kekaburan makna dari "kesepakatan para pihak" yang tertuang dalam Pasal 1 ayat (3) Peraturan Pemerintah Republik Indonesia Nomor 29 Tahun 2016 Tentang Perubahan Modal Dasar Perseroan Terbatas. Sehingga untuk dapat menjelaskan makna kesepakatan para pihak tersebut diperlukan adanya teori penafsiran hukum/interpretasi hukum.

Menurut Sudikno Mertokusumo $(1999,154)$, interpretasi atau penafsiran merupakan salah satu metode penemuan hukum yang memberikan penjelasan yang gamblang mengenai teks undangundang agar lingkup kaidah hukum dapat diterapkan sesuai dengan peristiwa tertentu. Kesebelas macam interpretasi yang ada, maka interpretasi yang paling cocok untuk digunakan untuk menjelaskan makna kesepakatan para pihak dalam Pasal 1 ayat (3) Peraturan Pemerintah Nomor 29 Tahun 2016 adalah interpretasi teleologis.

Interpretasi teleologis digunakan apabila pemaknaan suatu peraturan hukum ditafsirkan berdasarkan tujuan pembuatan aturan hukum dan apa yang ingin dicapai dalam masyarakat. Sehingga dengan interpretasi teleologis ini maka suatu perundang-undangan disesuaikan dengan situasi sosial 
yang baru. Penjelasan umum dalam Peraturan Pemerintah Republik Indonesia Nomor 29 Tahun 2016 menyebutkan bahwa latar belakang Pemerintah dalam mengeluarkan dalam Pasal Peraturan Pemerintah ini adalah dalam mengimplementasikan Pasal 33 ayat (4) Undang-undang Dasar Negara Republik Indonesia Tahun 1945 yaitu untuk menjalankan demokrasi ekonomi dalam pembangunan nasional yang diselenggarakan dengan prinsip kebersa,aan, efisiensi berkeadilan, berkelanjutan, berwawasan lingkungan, kemandirian serta menjaga keseimbangan kemajuan dan kesatuan ekonomi nasional masih mengalami kendala.

Hal tersebut dibuktikan dengan dalam rangka mempercepat proses pembangunan dan pertumbuhan ekonomi melalui penanaman modal dengan cara membuat kebijakan melalui pemberian fasilitas dan kemudahan bagi penanam modal masih rendah bahkan kontra produktif. Banyaknya peraturan justru makin membebani kalangan pelaku usaha termasuk penanam modal yang mengakibatkan daya saing di Indonesia makin menurun. Salah satu contohnya adalah pengaturan mengenai besaran modal dasar yang diatur dalam UUPT Tahun 2007 yang cukup sulit untuk dilaksanakan dan menyulitkan dunia usaha khususnya bagi pengusaha pemula.

Penjelasan umum dalam Peraturan Pemerintah Republik Indonesia Nomor 29 Tahun 2016 menyatakan bahwa tujuan Pemerintah dalam mengeluarkan dalam Peraturan Pemerintah Republik Indonesia Nomor 29 Tahun 2016 adalah untuk menghilangkan besaran minimal modal dasar yang telah diatur dalam UUPT Tahun 2007 sebesar Rp. 50.000.000,- (lima puluh juta rupiah) sebagaimana yang diatur dalam Pasal 32 ayat (1) UUPT Tahun 2007 dengan mendirikan PT dengan modal dasar dibawah Rp. 50.000.000,- (lima puluh juta rupiah).

Teori kontrak/ teori perjanjian menyatakan bahwa kontrak dikonstruksikan sebagai seuah persetujuan antara dua pihak atau lebih untuk men- ciptakan kewajiban hukum pada semua pihak, yaitu untuk melakukan (atau tidak melakukan) tindakan tertentu atau serangkaian tindakan terkait. Pengertian tersebut maka kesepakatan para pihak (konsensus) adalah suatu hal yang penting dalam rangka menciptakan adanya kepastian hukum dan adanya jaminan pelaksanaan setiap hal yang dimaksudkan oleh dan menjadi kebutuhan bagi pihak-pihak yang mengadakan transaksi bisnis.

Kesepakatan ditandai dengan adanya kesesuaian atau pertemuan maksud dari para pihak yang mengadakan transaksi bisnis dan adanya kehendak untuk saling mewujudkan tujuan masingmasing menjadi tujuan bersama. Jadi terciptanya suatu kesepakatan merupakan titik awal (starting point) pelaksanaan kontrak. Titik awal kesepakatan tersebut menjadi patokan/pedoman bagi para pembuat kontrak, karena pada saat itu terjadi pertemuan maksud dan kehendak para pihak dan sejak saat itu pula kontrak berikut hak dan kewajiban masing-masing pihak lahir atau ada.

Sehingga apabila dikaitkan dengan makna kesepakatan para pihak dalam Pasal 1 ayat (3) Peraturan Pemerintah Republik Indonesia Nomor 29 Tahun 2016, maka dalam menentukan besarnya modal dasar pendirian PT, hanya memerlukan adanya kesesuaian atau persetujuan antara pihak pendiri PT. Teori kesepakatan melahirkan sebuah asas terpenting yaitu asas kebebasan para pihak untuk menentukan apa saja yang akan disepakati yang dengan pengertian lain disebut dengan asas kebebasan berkontrak. Sesuai dengan ketentuan dalam asas kebebasan berkontrak, maka para pihak bebas dalam menentukan isi perjanjian/kontrak, yang mana dalam hal ini adalah para pihak bebas untuk menentukan besarnya modal dasar pendirian PT.

Sehingga, makna "berdasarkan kesepakatan para pihak" dalam Pasal 1 ayat (3) Peraturan Pemerintah Republik Indonesia Nomor 29 Tahun 2016 adalah para pendiri PT dapat mendirikan PT dengan modal dasar dibawah Rp. 50.000.000,- (lima puluh juta rupiah) asalkan dalam perjanjian pen- 
dirian PT tersebut telah mencapai kesesuaian atau disetujui oleh para pihak dalam pendirian PT.

\section{Akibat Hukum dari Perubahan Besaran Modal Dasar PT Menjadi Kesepakatan Pendiri PT}

Eksistensi pengaturan modal dasar PT yang semula diatur dalam KUHD sampai yang diatur dalam UUPT Tahun 2007 menunjukan adanya perubahan modal dasar PT yang semula besaran minimalnya tidak diatur dalam KUHD kemudian diatur dalam UUPT Tahun 1995 yaitu modal dasar PT ditentukan paling sedikit Rp. 20.000.000,- (dua puluh juta rupiah), kemudian dirubah lagi menjadi modal pendirian PT paling sedikit Rp. 50.000.000,(lima puluh juta rupiah). Hal ini menunjukkan bahwa perubahan pengaturan modal dasar PT semakin bertambah tinggi nilainya.

Perubahan pengaturan tentang modal dasar PT ini dikarenakan adanya perkembangan perekonomian yang cepat dan drastis. Suatu jumlah tertentu dalam waktu sekarang mungkin saja telah dipandang cukup, namun dalam waktu lima tahun mendatang menjadi tidak memadai lagi. Oleh karena itu, dengan adanya Pasal 32 ayat (3) UUPT Tahun 2007 memberikan kemungkinan perubahan besaran modal dasar PT yang menyimpangi besaran modal dasar yang diatur dalam Pasal 32 ayat (1) UUPT Tahun 2007. Dimana perubahan ketentuan Pasal 32 ayat (1) UUPT Tahun 2007 tidak perlu melalui revisi atau amandemen. Karena hal tersebut dianggap menghambat kebutuhan perkembangan hukum yang mendesak. Oleh karena itu, cukup melalui sarana hukum yang berbentuk Peraturan Pemerintah sehingga tidak perlu melalui proses yang berbelit dan melibatkan campur tangan Dewan Perwakilan Rakyat (DPR) atau badan legislatif.

Peraturan Pemerintah Republik Indonesia Nomor 29 Tahun 2016 Tentang Perubahan Modal Dasar Perseroan Terbatas diundangkan mengingat bahwa kebijakakan Pemerintah untuk memberikan kemudahan berusaha bagi pengusaha dalam mendirikan badan usaha PT (yang diatur dalam UUPT Tahun 2007) dalam pelaksanaannya terdapat substnsi-substansi yang cukup sulit untuk dilaksanakan dan menyulitkan dunia usaha, khususnya bagi pengusaha pemula.

Pemerintah memandang perlu memberikan kemudahan berusaha dan lebih menjamin ketertiban dunia usaha dalam investasi dengan mengubah besaran modal dasar yang dirasakan masih memberatkan bagi pengusaha pemula. Kemudahan tersebut adalah dengan menghilangkan besaran modal dasar pendirian PT menjadi berdasarkan kesepakatan para pihak pendiri PT.

Pasal 1 Angka 1 UUPT Tahun 2007 menyatakan bahwa:

"Perseroan Terbatas, yang selanjutnya disebut Perseroan, adalah badan hukum yang merupakan persekutuan modal, didirikan berdasarkan perjanjian, melakukan kegiatan usaha dengan modal dasar yang seluruhnya terbagi dalam saham dan memenuhi persyaratan yang ditetapkan dalam Undang-Undang ini serta peraturan pelaksanaannya."

Ketentuan Pasal 1 angka 1 UUPT Tahun 2007 tersebut menyatakan bahwa PT merupakan badan hukum yang lahirnya melalui proses hukum dalam bentuk memerlukan adanya pengesahan Pemerintah. Hal tersebut dinyatakan dalam Pasal 7 ayat (4) UUPT Tahun 2007 yang menyatakan bahwa: "Perseroan memperoleh status badan hukum pada tanggal diterbitkannya Keputusan Menteri mengenai pengesahan badan hukum Perseroan."

Keberadaan PT sebagai badan hukum dibuktikan dengan akta pendirian yang di dalamnya tercantum Anggaran Dasar Perseroan. Apabila Anggaran Dasar telah mendapat pengesahan Menteri, maka PT akan otomatis menjadi "subjek hukum koorporasi" (subject to corporation law) yang pada dasarnya sifat eksistensinya sebagai subjek hukum perseroan adalah terus menerus dan abadi 
(perpetual). Bahkan sekiranya dalam Anggaran Dasar ditentukan jangka waktu berdirinya, hal itu tidak mengurangi keabadiannya untuk jangka waktu tersebut. Kematian, pengalihan dan berhentinya pemegang saham dan diberhentikan atau diganti anggota Direksi maupun karyawan PT tidak mempengaruhi dan tidak menimbulkan akibat terhadap kelanjutan hidup dan eksistensi PT (Harahap, 2015, 37).

Unsur utama dari PT sebagai badan hukum yaitu memiliki harta sendiri yang terpisah dari pemegang saham selaku pemilik, karakteristik kedua dari PT sebagai badan hukum adalah adanya tanggung jawab terbatas dari pemegang saham sebagai pemilik perusahaan dan pengurus perusahaan (Erman, 2011, 191).

Perseroan sebagai badan hukum merupakan bentuk organisasi bisnis yang sangat penting dalam perekonomian dunia. Hal tersebut dikarenakan perseroan mempunyai peranan untuk membangkitkan perkembangan ekonomi yang memiliki kapasitas besar dalam mengumpulkan modal (capital). Hukum Perseroan (coorporate law) memperbolehkan orang menanamkan uang mereka dalam Perseroan tanpa dibebani dengan tanggung jawab yang tidak terbatas dan juga tanpa dibebani tanggung jawab pengurusan perseroan atas diri penanam modal.

Teori badan hukum yaitu teori organ oleh Otto von Gierke mengemukakan bahwa badan hukum merupakan bentuk usaha mandiri dengan adanya tanggung jawab terbatas (legal entity) merupakan realitas hukum yang mempunyai kehendak dan kemauan sendiri yang dijalankan oleh alat-alat perlengkapannya (Harris dan Anggoro, 2010, 37).

Hal tersebut sebagaimana dirumuskan dalam Pasal 3 ayat (1) UUPT Tahun 2007 yang menyatakan bahwa: "Pemegang saham Perseroan tidak bertanggung jawab secara pribadi atas perikatan yang dibuat atas nama Perseroan dan tidak bertanggung jawab atas kerugian Perseroan melebihi saham yang dimiliki."
Ketentuan dalam Pasal 3 ayat (1) tersebut, maka hukum perseroan membatasi tanggung jawab perseroan dengan ketentuan sebagai berikut: (Harahap, 2015, 74).

1. Pemegang saham perseroan tidak bertanggung jawab secara pribadi (personal liability) atas perikatan yang dibuat atas nama perseroan maupun atas kerugian yang dialami perseroan;

2. Resiko yang ditanggung pemegang saham hanya sebesar investasinya atau tidak melebihi saham yang dimilikinya pada perseroan; dan

3. Dengan demikian, pada prinsipnya pemegang saham tidak bertanggung jawab secara pribadi atau secara individual atas hutang yang ditimbulkan oleh perseroan.

Substansi pokok yang diatur dalam Peraturan Pemerintah Republik Indonesia Nomor 29 Tahun 2016 Tentang Perubahan Modal Dasar Perseroan Terbatas adalah menghilangkan besaran modal dasar pendirian PT menjadi berdasarkan kesepakatan para pihak pendiri PT. Oleh karena itu, apabila dikaitkan dengan adanya pertanggungjawaban perseroan yang terbatas tersebut, maka menimbulkan dampak tidak adanya perlindungan bagi pihak ketiga. Hal tersebut dikarenakan persyaratan modal dasar minimal dimaksudkan agar ketika PT didirikan setidak-tidaknya sudah memiliki modal yakni sebesar modal yang disetor dan juga dapat menjadi jaminan bagi setiap tagihan dari pihak ketiga terhadap PT dan semuanya ini bertujuan untuk memberikan jaminan perlindungan terhadap tagihan pihak ketiga.

Selain itu tujuan dari dikeluarkannya Peraturan Pemerintah Republik Indonesia Nomor 29 Tahun 2016 Tentang Perubahan Modal Dasar Perseroan Terbatas ini adalah dalam rangka memberikan kepastian hukum bagi pelaku pembangunan ekonomi nasional khususnya dalam memulai usaha. Dengan dihilangkannya besaran minimal modal dasar dalam pendirian PT justru akan menimbulkan tidak adanya kepastian hukum dalam 
menentukan modal dasar dalam pendirian PT. Hal tersebut akan berdampak juga pada tidak adanya kepercayaan masyarakat yang akan melakukan kerja sama dengan PT tersebut.

\section{Formulasi Terhadap UUPT Agar dapat Memberikan Kepastian Hukum Bagi Para Pihak}

Pengaturan mengenai besaran modal dasar PT pertama kali diatur dalam UUPT Tahun 1995, yaitu mengatur mengenai besaran modal dasar pendirian PT paling sedikit sebesar Rp. 20.000.000,(dua puluh juta rupiah). Namun, dalam perkembangannya UUPT Tahun 1995 tersebut dirasakan tidak sesuai lagi dengan perkembangan ekonomi dan dunia usaha yang semakin pesat baik secara nasional maupun internasional. Sehingga melalui UUPT Tahun 2007, Pemerintah menaikkan besaran modal dasar pendirian PT menjadi paling sedikit Rp. 50.000.000,- (lima puluh juta rupiah). Hal ini menunjukkan bahwa perubahan pengaturan modal dasar PT semakin bertambah tinggi nilainya.

Pemerintah mengeluarkan Perturan Pemerintah Republik Indonesia Nomor 29 Tahun 2016 tentang Perubahan Modal Dasar Perseroan Terbatas untuk menghilangkan besatan modal dasar dalam pendirian PT. Namun, pengaturan mengenai perubahan modal dasar PT dalam dalam Perturan Pemerintah tersebut berpotensi untuk tidak memberikan perlindungan hukum bagi pihak ketiga. Pihak ketiga yang dimaksudkan disini adalah pihak-pihak yang melakukan kerja sama atau mempunyai hubungan hukum dengan PT. hal tersebut dikarenakan adanya pertanggungjawaban terbatas yang memisahkan tanggung jawab pemegang saham secara pribadi (personal liability) atas perikatan yang dibuat atas nama perseroan maupun atas kerugian yang dialami perseroan.

Gustav Radbruch dalam teori cita hukum mengemukan bahwa dalam mewujudkan tiga nilai dasar hukum (nilai keadilan, nilai kemanfaatan dan nilai kepastian hukum) seringkali terjadi benturan nilai. Oleh karena itu, Gustav Radbruch mengemukakan suatu "asas prioritas" yang menyebutkan bahwa dalam tujuan hukum hendaknya pertamatama wajib memprioritaskan keadilan, kemudian disusul dengan kemanfaatn dan terakhir untuk kepastian hukum, dengan harapan dengan diterapkannya asas prioritas ini dapat terhindar dari terjadinya konflik-konflik yang berkepanjangan. Hal tersebut berati, apabila teori tujuan hukum dikaitkan dengan perubahan pengaturan modal dasar dalam pendirian PT yang diatur dalam Perturan Pemerintah Republik Indonesia Nomor 29 Tahun 2016 tentang Perubahan Modal Dasar Perseroan Terbatas, maka seharusnya yang dikedepankan terlebih dahulu adalah nilai keadilan para pihak.

Formulasi yang diberikan Penulis terhadap Undang-Undang Perseroan Terbatas agar dapat memberikan kepastian hukum bagi para pihak adalah "Modal dasar Perseroan paling sedikit Rp. 100.000.000,- (seratus juta rupiah). Hal tersebut dikarenakan tujuan dari Pasal 32 ayat (3) UUPT Tahun 2007 adalah untuk mengantisipasi adanya perubahan keadaan perekonomian dalam hal terjadi inflansi. Selain itu besaran modal dasar Rp. 50.000.000,- (lima puluh juta) kurang memberikan perlindungan hukum bagi pihak ketiga mengingat PT adalah berbentuk badan hukum yang mempunyai tanggung jawab yang terbatas.

\section{Penutup}

\section{Kesimpulan}

Berdasarkan hasil uraian dari pembahasan pada tesis ini, disimpulkan bahwa makna dari kesepakatan para pihak pada Pasal 1 ayat (3) Peraturan Pemerintah Nomor 29 Tahun 2016 Tentang Perubahan Modal Dasar Perseroan Terbatas adalah para pendiri PT dapat mendirikan PT dengan modal dasar dibawah Rp. 50.000.000,- (lima puluh juta rupiah) asalkan dalam perjanjian pendirian PT tersebut telah mencapai kesesuaian atau disetujui 
oleh para pihak dalam pendirian PT. Akibat hukum yang ditimbulkan dari perubahan besaran modal dasar PT menjadi kesepakatan para pihak adalah tidak adanya perlindungan hukum bagi pihak ketiga. Hal tersebut terkait adanya pertanggungjawaban terbatas PT sebagai badan hukum. Akibat hukum lainnya adalah tidak adanya kepastian hukum bagi para pendiri PT untuk menentukan besaran modal dasar dalam pendirian PT. Formulasi yang diberikan terhadap Undang-Undang Perseroan Terbatas agar dapat memberikan kepastian hukum bagi para pihak adalah "Modal dasar Perseroan paling sedikit Rp. 100.000.000,(seratus juta rupiah). Hal tersebut dikarenakan tujuan dari Pasal 32 ayat (3) UUPT Tahun 2007 adalah untuk mengantisipasi adanya perubahan keadaan perekonomian dalam hal terjadi inflansi. Selain itu besaran modal dasar Rp. 50.000.000,(lima puluh juta) kurang memberikan perlindungan hukum bagi pihak ketiga mengingat adanya karakteristik PT sebagai badan hukum yaitu adanya pertanggungjawaban yang terpisah.

\section{Saran}

Perubahan besaran minimal modal dasar pendirian PT akan menimbulkan akibat hukum yaitu tidak adanya perlindungan hukum bagi pihak ketiga. Oleh karena itu, seharusnya Pemerintah tidak hanya memberikan kemudahan berusaha bagi pengusaha pemula, namun juga memperhatikan jaminan perlindungan bagi pihak ketiga yang berhubungan dengan PT. Pengusaha pemula yang belum mempunyai dana Rp. 50.000.000,-- (lima puluh juta) sebagai persyaratan pendirian PT yang ditentukan dalam UUPT Tahun 2007, maka masih terdapat bentuk usaha lain yang dapat dipergunakan dalam memulai usaha, seperti CV dan Firma

\section{DAFTAR PUSTAKA}

\section{Buku}

Hadhikusuma, R.T. Sutantya R dan Sumantoro, 1992, Pengertian Pokok Hukum Perusahaan, Rajawali, Jakarta.

Harahap, M. Yahya, 2015, Hukum Perseroan Terbatas, Sinar Grafika, Jakarta.

Harris, Freddyn dan Teddy Anggoro, 2010, Hukum Perseroan Terbatas: Kewajiban Pemberitahuan Direksi Sebagai Pengurus dan Wakil Perseroan, Ghalia Indonesia, Jakarta.

Hartono, Sri Redjeki, 1985, Bentuk-Bentuk Kerjasama dalam Dunia Niaga, Fakultas Hukum Universitas 17 Agustus 1945, Semarang.

Kansil, Christine S.T, 2009, Seluk Beluk Perseroan Terbatas Menurut Undang-Undang Nomor 40 Tahun 2007, Rineka Cipta, Jakarta.

Mertokusumo, Sudikno, 1999, Mengenal Hukum Suatu Pengantar, Liberty, Yogyakarta.

Raharjo, Handri, 2013, Hukum Perusahaan, Pustaka Yustisia, Yogyakarta.

Rajaguguk, Erman, 2011, Butir-Butir Ekonomi, Lembaga Studi Hukum dan Ekonomi Fakultas Hukum Universitas Indonesia, Jakarta.

Sjahdeini, Sutan Remy, 1993, Kebebasan Berkontrak dan Perlindungan yang Seimbang Bagi Para Pihak dalam Perjanjian Kredit Bank di Indonesia, Institut Bankir Indonesia, Jakarta.

Supramono, Gatot, 2007, Hukum Perseroan Terbatas, Djambatan, Jakarta.

Peraturan Perundang-undangan

Undang-Undang Dasar Negara Republik Indonesia Tahun 1945.

Kitab Undang-Undang Hukum Perdata.

Kitab Undang-Undang Hukum Dagang.

Undang-Undang Nomor 1 Tahun 1995 tentang Perseroan Terbatas. 


\section{Makna Kesepakatan Para Pihak terhadap Perubahan Modal Dasar Perseroan Terbatas}

Yohana Feryna

Undang-Undang Nomor 40 Tahun 2007 tentang Perseroan Terbatas.

Undang-Undang Nomor 20 Tahun 2008 tentang Usaha Mikro, Kecil dan Menengah.
Peraturan Pemerintah Republik Indonesia Nomor 7 Tahun 2016 tentang Perubahan Modal Dasar Perseroan Terbatas.

Peraturan Pemerintah Republik Indonesia Nomor 29 Tahun 2016 tentang Perubahan Modal Dasar Perseroan Terbatas. 